\title{
Opportunities for the Development of North Asia in the "One Belt - One Road" Project: Problems and Solutions
}

\author{
Suocheng Dong ${ }^{2}$, Tamir Boldanov ${ }^{1,2,3, *}$, Arnold Tulokhonov ${ }^{1}$, Tcogto \\ Bazarzhapov $^{1,2,3}$, Ayana Yangutova ${ }^{2,3}$, Yang Yang ${ }^{2}$, Fujia Li $^{2}$ \\ ${ }^{1}$ Baikal Institute of Nature Management, Siberian branch of the Russian Academy of sciences, Ulan-Ude, \\ Russia \\ ${ }^{2}$ Institute of Geographic Sciences and Natural Resources Research, Chinese Academy of Sciences, Beijing, \\ China \\ ${ }^{3}$ University of Chinese Academy of Sciences, Beijing, China \\ *Corresponding author. Email: tboldanov2018@igsnrr.ac.cn
}

\begin{abstract}
The economy is entering a new phase of post-covid development. It is necessary to take into account new trends in economic development and transport corridors. The study analyzes the existing economic corridors, examines the existing opportunities for further development of Russian-Chinese cooperation on mutually beneficial terms based on the development of economic corridors and their impact on further development, taking into account economic and geographical analyses. The cooperation programs of the regions of the Far East and Eastern Siberia, as well as the Northeast of China, are analyzed. In conclusion, we propose a list of main factors for consideration, changes and additions that can be made to future programs between the Russian Federation, Mongolia and China, which will be mutually beneficial and have a cumulative effect.
\end{abstract}

Keywords: "One belt - one road", China-Mongolia-Russia cooperation, transport corridor, economic corridor, international cooperation

\section{INTRODUCTION}

Currently, the economic interests of many countries in Asia and Europe are connected with the implementation of the mega-project "One Belt-One Road". Traditionally, the main cargo from Asia to Europe goes by sea through the Suez Canal. The main factor affecting the efficiency of transportation is the duration of transportation. Transportation along the Northern Sea Route presents certain prospects. However, icebreaking support is required here. Therefore, transport systems are developing through Western China and Kazakhstan, which can continue through the European part of Russia, Belarus or through the Caspian Sea and then through Turkey.

However, the most promising project for the development of trade and economic relations between China, Mongolia and Russia is the improvement of existing cargo flows using the Trans - Siberian Railway and its extensions to China through the stations of Naushki, Zabaikalsk and the automobile crossing in Kyakhta.

In 2015, the Heads of China, Russia and Mongolia signed an agreement in Ufa on the creation of the Northern Economic Corridor project, which connects Central China, Mongolia and Siberia into a single economic space [1].

The program included almost all issues of international cooperation and consists of 7 major sections. In addition, a list of 32 technical projects is attached to the program, including transport infrastructure, cooperation in the field of industry, transport, energy, agriculture, modernization of checkpoints, customs, inspection and quarantine, cooperation in the field of environmental protection and ecology, scientific and technical cooperation and education, humanitarian cooperation, medicine and healthcare. 
The main purpose of the study is to analyze the current state of the China-Mongolia-Russia economic corridor, as well as to assess the ways of development of this economic corridor, taking into account the existing infrastructure, geographical factors (the shortest distance and the minimum number of cargo transshipment) and the mutual orientation of the leadership of the states.

\section{METHOD AND RESULT}

In the present research, different literary sources, archival data, official statistical reports, cartographic materials, reports of independent organizations, as well as expeditionary data of participants have been used.

For the regions of the Siberian Federal District, the Northern Economic Corridor in its significance and direction practically repeats the role of the Great Tea Road, which breathed life into Kyakhta and other cities of Southern Siberia in the $19^{\text {th }}$ century.

Today, such a highway can give a new impetus to the development of foreign trade in the Siberian economy, which in terms of the gross regional product $(10.4 \%$ of the volume of the Russian Federation) significantly exceeds the indicators of the Far Eastern region (5.7\%). In terms of foreign trade turnover, due to the distance from international sales markets, the Siberian economy is significantly inferior to the indicators of the Far East (SFO -37\%, Far Eastern Federal District - 48.1\%) and even more so to the country's level $(54.5 \%)$.

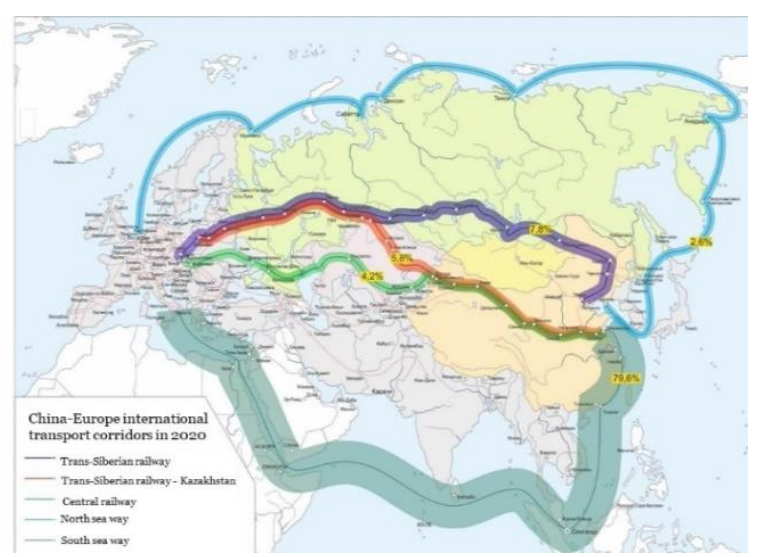

Figure 1. China-Europe International transport corridor

The development of the Northern Economic Corridor represents the shortest route between central China and Europe (Figure 1). If eastern China is oriented to the trade ports of the Pacific coast, and trade along the Silk Road is more profitable for western China, then transit through Mongolia presents new opportunities for the provinces of northern and central China to enter the Russian and European markets.

It should be noted that the trade turnover between the EU and China is $98 \%$ served by the cheapest sea transport, mainly through the Suez canal. Almost $80 \%$ of them are containerized cargo, which is also adapted to rail transport. 55\% of imports from China to the EU countries are also provided by container cargo. Transit container cargo traffic from China to the EU and back in 2010 - 2016 increased from 5.6 TEU thousand to almost 100 TEU, and in 2017 it has already made 262 thousand TEU. Russian exports in containers do not exceed $2 \%$ (Table 1).

Table 1. Comparative dynamics of container train departure frequency and freight volumes China-

Europe-China [2]

\begin{tabular}{|l|l|l|l|l|}
\hline & 2011 & 2013 & 2015 & 2016 \\
\hline $\begin{array}{l}\text { Volume of container } \\
\text { traffic, thou. TEU }\end{array}$ & 7 & 20 & 40 & 74 \\
\hline Train per week & 0.3 & 2 & 16 & 33 \\
\hline
\end{tabular}

The benefits of developing economic relations with the two neighbours are also quite clear for Mongolia. Thus, there are common interests for all parties involved. However, against this background, there is also a specific understanding and, moreover, the implementation of the signed agreement. The Silk Road Fund allocates more than $\$ 40$ billion for the implementation of key transport projects alone. Special funding has also been allocated for the Chinese Academy of Sciences for the purpose of scientific research along the Northern Economic Corridor zone.

The implementation of such a magnificent megaproject represents an opportunity to integrate the geopolitical, economic and humanitarian interests of the three largest states of North Asia. However, against this background, each of the parties has its own interests, which could be identified at the early stages of possible contradictions.

In general, the Northern Economic Corridor, a modern analogue of the Tea Road, is a competitor of the Silk Road in terms of the transit of some goods in the East-West transport system. However, unlike the transportation along the Silk Road through Western China and Kazakhstan, there is already an operating transport channel here, including road and rail transports with access to the Trans-Siberian Railway, and in the future to the Baikal-Amur highway. 
According to E. Y. Vinokurov et al [2] transit container rail shipments from the EU to China, expressed in those YEARS, show their growth from 1.3 thousand tons. TEU in 2010 to more than 50 thousand. TEU in 2016. If until 2014 almost all transit rail container cargo traffic from the EU to China passed through Zabaikalsk (95-100\%), in 2016 its share decreased to $22 \%$, and $2 / 3$ of containers (about 34 thousand tons). TEU is transported through Kazakhstan's Dostyk and another 10\% through Naushki. Transit container cargo traffic in the opposite direction from China to the EU increased almost 20 times between 2010 and 2016. At the same time, the share of the Dostyk border crossing increased from $1 \%$ to $67 \%$, and the share of Zabaikalsk decreased from $99 \%$ to $20 \%$ (Figure 2).

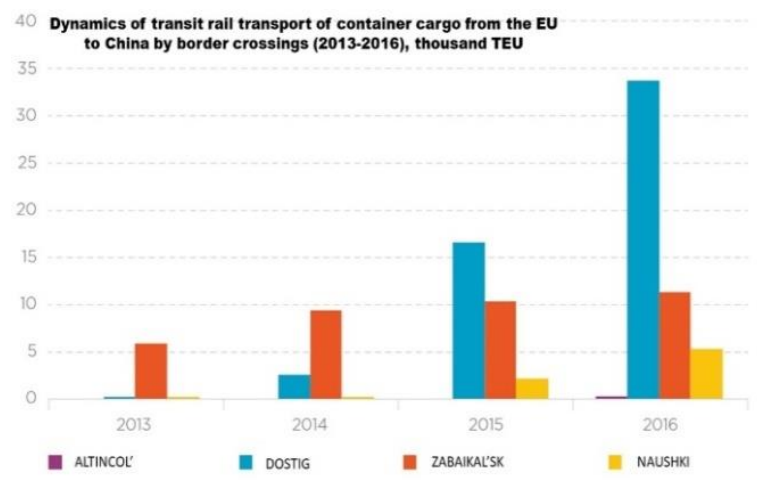

Figure 2. Dynamics of transit rail transport of container cargo from the EU to China by border crossings (2013-2016), thousand TEU

Within the framework of the Northern Economic Corridor, we can consider the increasing volumes of liquefied gas transportation along the Northern Sea Route from the port of Sabbeta (Yamal Peninsula) to the countries of the Asia-Pacific region. Of particular interest, in connection with the US trade sanctions, the supply of such energy carriers is for China.

The absolute advantage of the Northern Economic Corridor is the minimum number of customs crossing points and the safety of goods. It should be noted that in a number of Chinese state documents, the vector of the Silk Road to Europe passes the south of the Caspian Sea through Iran and Turkey and even bypassing Kazakhstan, which is clearly to the detriment of the interests of the states of the Eurasian Economic Union and the SCO countries. However, it should be assumed that in the conditions of political instability in Central Asia, such a route has no special prospects.

In this situation, in order to really claim large volumes of international traffic along the Northern
Economic Corridor, it is necessary to radically modernize the railway and automobile routes from the Trans-Siberian Railway, through Mongolia and to Central China.

Currently, the single-track diesel-powered track is physically and morally outdated. At the same time, the issue of building a new Erlian-Naushki railway remains fundamentally important, where each of the parties is interested in laying its own standard gauge.

In the next five years, it is planned to build about 11 thousand $\mathrm{km}$ of high-speed highways in China, which will connect 80 of the country's largest cities and create the possibility of moving to any part of the country in no more than 8 hours, and the total allocations for the construction of railways in China in 2016 amounted to 8 trillion rubles.

Currently, the Beijing - Ulaanbaatar - Ulan-Ude Moscow road and rail route represents the shortest distance in the "One Belt, One Road" megaproject between China and Europe, in which a strategic interest for both Russia and Mongolia remains. Moreover, it is the Mongolian export transit that in the future can increase cargo traffic in the direction of the Far Eastern seaports of Russia. It should be noted that at present, the channels of entry of Islamic capital into the Mongolian economy are being activated, with its orientation towards the Muslim part of Western China. All these factors of political and economic cooperation with Mongolia are of particular importance in the context of increasing Western sanctions.

For the implementation of the directives of the President of the Russian Federation V. V. Putin on the priority development of the economic space of Siberia and the Far East, it is fundamentally important not just transit transportation, but most of all the creation of industrial and agricultural clusters along these corridors, which should become the basis for strengthening Russia's export potential in trade with the Asia-Pacific countries [3].

However, the solution of this problem is hindered by the lack of state planning and coordination in transit transport, including the competition of rail, road and pipeline transport. Instead of solving state problems, industry corporations and private companies solve their local problems. At the same time, the interests of the manufacturer and consumer of goods and the carrier are not always taken into account, including the classical triad of the transport economy: speed, cost and safety of goods [4].

For these reasons, the first item in the list of projects of the Program for the creation of the 
Northern Economic Corridor of China is the point of comprehensive modernization and development of the Central Railway Corridor (Tianjin-Beijing-ErlianUlaanbaatar-Ulan-Ude) with a total length of 2,200 $\mathrm{km}$, the study of the economic feasibility of building a second track and electrification. In addition, the possibility of building a Western railway corridor with access to Tyva, an Eastern one - to Choibalsan - Zabaikalsk and the prospects of building a highspeed railway Moscow-Beijing through Mongolia are being considered.

At present, experimental truck transportation is passing through two borders. The new route no longer requires cargo transshipment and processing of additional customs documents, and the distance from the south of China to the European part of Russia will be reduced by 1.4 thousand $\mathrm{km}$, the travel time by 4 days [2].

According to Rosavtotrans calculations, by 2020, cargo traffic on this route will be grown by $17-20 \%$, which in principle corresponds to the average annual growth in trade volumes between Russia and China. In addition, the existing transportation is effective in two directions [5].

When implementing this Memorandum, Mongolia becomes a key player in the transit of goods from China to Europe, and all its participants are equally interested in this. The issue of track width and the organization of a logistics center comes to the fore of the construction of railways through Mongolia. The interest of the Chinese participants is in the construction of a through narrow track up to the Russian border, which does not quite suit the Russian side.

The most likely option is to build a logistics center in Ulaanbaatar, taking into account the mutual interests of all project participants and, first of all, Russia, which gets the opportunity to transit and handle a significant volume of cargo transportation on the Trans - Siberian Railway coming from the Asia-Pacific region. In addition to the growth in the volume of rail and road transport, it is proposed to combine the construction of a main transit gas pipeline through Mongolia to China in this economic corridor, to increase the capacity of the power transmission line for gasification and electrification of the main industrial centers of Mongolia and, first of all, its capital - Ulaanbaatar [6].

In addition to solving the socio-economic problems, it is thus possible to close the problem of building hydroelectric power stations on the Selenga River and thereby eliminate the emerging environmental threats to the ecosystem in the Baikal Lake basin. However, regardless of the choice of the direction of railways and highways, there are certain conditions for increasing their efficiency.

First of all, for all transit territories, the transportation of goods and passengers should activate their economy by creating industrial clusters, transport hubs and other employment centers.

Another condition for increasing the efficiency of the main routes is the oncoming transit flow between the two end stations. Meanwhile, at present, the volume of transit traffic from Asia to Europe through Russia is exactly 2 times higher than the volume of traffic in the opposite direction, i.e. half of the vehicles go to the east unloaded, which negatively affects the pricing policy of the manufacturer [2].

In a market economy, pricing is largely determined by the level of industry competition. For this reason, the real competition for rail transport is road transport. With the construction of main oil and gas pipelines, the volume of transportation of petroleum products, which once accounted for up to half of the volume of railway cargo, has significantly decreased, which forces railway workers to increase the cost of transportation, cancel unprofitable suburban trains, and reduce passenger train stops.

In a planned economy, the interests of the state and its population were primarily determined. Today, unfortunately, under the slogan of a market economy, the state has practically eliminated the pricing of strategic infrastructure tasks, and, nevertheless, these distortions should be taken into account in all economic programs at the federal and regional levels.

\section{DISCUSSION}

The proposed options for the development of the transport industry in North Asia allow us to diversify the transportation of goods and passengers in all strategic directions. At the same time, we are not talking about the competition of main highways, but most of all about creating a synergistic transport effect that significantly increases the economic growth of all three states included in the Northern Economic Corridor project.

A special place in the development of the economy of North Asia along the zone of the megaproject "One Belt-One Road" is occupied by the solution of environmental problems. These include the growth of industrial pollution, the destruction of agricultural land productivity, the processes of desertification, and the shortage of freshwater. These 
phenomena are especially relevant for Northern China and Central Asia. As a result of the overexploitation of the water resources of Amu-and Syr Darya, the area of the Aral Sea has been catastrophically reduced.

In the near future, water conflicts are expected in the basins of the transboundary rivers Irtysh, Ural, Selenga, Amur, which cross the state borders of China, Kazakhstan, Mongolia and Russia. It is necessary to urgently develop joint water use programs.

In addition to geopolitical interests, routes to China represent an important transit direction for trade with the northern and central regions of China that do not have direct access to the sea or western borders. Meanwhile, the main volumes of China's trade with Europe in recent years are increasingly differentiated in two main areas. The eastern coastal provinces are most focused on sea transportation through the Suez Canal, through which more than $90 \%$ of Chinese cargo goes, and in the western direction through Kazakhstan. In both cases, transport flows are outside the sphere of Russian interests.

For Russia, the main factor in the socio-economic development of Siberia and the Far East is the advanced development of the regions adjacent to the Trans-Siberian Railway. From this point of view, transit traffic from Mongolia is of strategic importance for Russia.

In addition, given the limited prospects for the development of Russian export routes and bypassing the Russian territory on its Northern, Eastern and southern borders, the task of implementing the Northern economic corridor project (the "Steppe way"), combining the interests of Russia, Mongolia and China with the construction of the Eastern Siberia - Mongolia - Northern China gas pipeline, is becoming increasingly urgent.

From this point of view, the main economic priority for the development of Russian export policy is the expansion of transport through the customs posts of Zabaikalsk and Naushki, and first of all, the radical modernization of the Ulan-Ude-UlaanbaatarZamyn-UD railway with its electrification and the laying of a second track according to Russian standards as the shortest distance between Europe and Beijing.

The creation of the East Asian Energy Ring, which combines the interests of our eastern neighbours interested in obtaining Russian electricity from the Zeyskaya and Bureyskaya HPPs, can significantly increase the efficiency of the economy in the zone of the Mongolian Transport Corridor.

\section{CONCLUSIONS}

However, a new factor of isolation of the eastern territories of Russia is added to the Western sanctions. It is quite possible to assume that with the growth of such trends, the only latitudinal railway connecting the European and Asian parts of the country risks turning from a transit into a dead-end internal highway, which may again turn the Far East into the Russian periphery.

As part of the implementation of the "One Belt, One Road" project, China's foreign economic relations are developing in two opposite directions, bypassing Russia. For eastern China, the main cargo to Europe goes through its seaports, and for western China, rail transportation through the Xinjiang Uygur Autonomous Region and further to Kazakhstan is increasing.

Such vectors of transit trade of China significantly narrow the possibilities of transit

Russian transportation using the Trans-Siberian Railway, for which only the transportation of products from the regions of Northern and Central China remains.

In addition, there is an absolute transport asymmetry of Russian exports and imports, when containers from our main trading partners are mainly on open platforms, and covered and special wagons in which raw materials were exported are mostly returned empty. At the same time, official government documents state that less than $5 \%$ of the country's transit potential is used in transport, and transit through Russia accounts for less than $1 \%$ of the trade turnover between Europe and Asia.

Overall, these factors determine the main directions of scientific research that should increase the efficiency of economic development of the vast territory of North Asia along the zone of the "One Belt, One Road" megaproject, actively develop cultural, scientific and educational cooperation between China, Russia and Mongolia.

Our suggestions:

1. In the context of globalization and the dynamics of global political and economic processes, the countries of North Asia should have a diversified transport system that reflects their interests in all strategic areas; 
2. At the same time, the construction of transport infrastructure is not an end in itself, but most of all it is a means of developing the regional economy that creates a cumulative effect;

3. A necessary condition for improving the efficiency of the economy is the search for common benefits, competing vehicles and directions, the organization of oncoming cargo and passenger flows in the interests of all states, not individual companies;

4. The development of the economy of North Asia requires new environmentally safe technologies for processing natural resources and water use programs in the basins of transboundary rivers.

5. The solution of the current economic problems between our countries should be accompanied by the development of long-term plans for scientific, educational and cultural cooperation based on the principles of sustainable development.

\section{AUTHOR'S CONTRIBUTIONS}

Suocheng Dong conceived and designed the experiments, authored or reviewed drafts of the paper, and approved the final draft. Tamir Boldanov conceived and designed the experiments, performed the experiments, analyzed the data, prepared figures and/or tables, authored or reviewed drafts of the paper, and approved the final draft. Arnold Tulokhonov conceived and designed the experiments, authored or reviewed drafts of the paper, and approved the final draft. Tcogto Bazarzhapov authored or reviewed drafts of the paper, and approved the final draft.

Ayana Yangutova authored or reviewed drafts of the paper, and approved the final draft. Yang Yang authored or reviewed drafts of the paper, and approved the final draft. Fujia $\mathrm{Li}$ authored or reviewed drafts of the paper, and approved the final draft.

\section{ACKNOWLEDGMENTS}

The research was funded by the CAS-TWAS president's fellowship for international doctoral students.

\section{REFERENCES}

[1] Memorandum of Understanding between the Russian Federation, the People's Republic of China and Mongolia on the development of a program for the creation of the Russia - China Mongolia economic corridor., 2015 URL: http://economy.gov.ru/minec/press/ news/2015090706

[2] Vinokurov E. Y., Lopyrev V. G., Tikhomirov A. A. Tokarev T. V. 2018. Silk road transport corridors: potential growth of cargo flows through the EEU. Saint Petersburg Eurasian development bank. Center for integration research. Report №. 49.,74 p (in Russian) DOI: https://doi.org/10.13140/RG.2.2.11793.53601

[3] State program of the Russian Federation "Socioeconomic development of the Far East and the Baikal region" (approved by the order of the Government of the Russian Federation of March 29, 2013 N 466-p) (in Russian)

[4] Tulokhonov A. K. 2020. Geographical space of New Russia: the past, the present and the future. Ulan-Ude, ECOS publishing house, 352p. (in Russian)

[5] Razina E. The Growth Pandemic/ / Kommersant "Logistics". Appendix No. 192 of 20.10.2020, page 1 URL: https://www.kommersant.ru/doc/4538639

[6] Barsukov Y. Gazprom will look at China across the steppes // Kommersant, №163, 10.09.2019, 7 p. (in Russian) 